utilization of agricultural, sylvicultural and pastoral soils ; traditional systems of agriculture ; possibility of utilization and transformation of shifting cultures; large-scale trials of agricultural mechanization; fertilizers and amendments ; improvement of swampy soils. The evolution of the arid zones in Africa will also be discussed. Immediately after the Conference, the Fifth International Congress of Soil Science will be held in Léopoldville, and after this Congress a number of excursions will be made in the Belgian Congo. Further information regarding the Conference can be obtained from the Inter-African Bureau for Soils at 57 rue Cuvier, Paris $5^{\mathrm{e}}$.

\section{Optical Conferences in Italy}

Two conferences of optical interest are being held this September in Italy, the first being an international symposium on infra-red radiation at the University of Parma during September 3-7. This is being sponsored by the International Union of Physics, the International Commission for Optics and other bodies in Italy, and will commemorate the hundredth anniversary of the death of Macedonio Melloni, the founder of infra-red studies at Parma. Further particulars of this meeting can be obtained from Prof. G. Polvani, president of the Italian Physical Society, Via Saldini 50, Milano. The second conference will be in Florence at the National Optical Institute of Italy during September 10-16, and will be on "Problems in Contemporary Optics". The subjects to be discussed are optics and information, non-classical focusing devices, optical problems of television, optical surface manufacturing, threedimensional optics and retinal problems. Details of this meeting can be obtained from Prof. G. Toraldo di Francia, Instituto Nazionale di Ottica, ArcetriFirenze.

\section{Autumn Meeting in Switzerland of the Institute of Metals}

THE autumn meeting of the Institute of Metals will be held this year in Switzerland during September 6-14, by invitation of the Société Swisse des Constructeurs de Machines and the Association Suisse pour l'Essai des Matériaux. The meeting will open in Zurich on September 6 and then will move to Montreux on September 11. On the morning of the first day the Institute of Metals (Platinum) Medal for 1953 will be presented to Dr. Georg Masing (Göttingen), and then two papers on grain refinement will be read and discussed. The rest of the meeting will be devoted to excursions to various places of interest in Switzerland, including a large number of engineering and metallurgical works. All arrangements for booking accommodation in Switzerland should be made before July 31 through the Post-Order Department, Thos. Cook and Son, Ltd., Berkeley Street, London, W.1, quoting POD/S/22222.

\section{Announcements}

The Dr. W. S. Bruce Memorial Prize for 1954, commemorating Dr. W. S. Bruce, the Scottish explorer and scientific investigator in polar regions, has been awarded to Dr. R. M. Laws, of the National Institute of Oceanography, for his investigations in the South Orkney Islands and South Georgia, particularly in the biology and life-history of elephant seals. The committee of award is appointed by the Royal Physical Society of Edinburgh, the Royal Scottish Geographical Society and the Royal Society of Edinburgh.
THE trustees of the Ciba Foundation have appointed Prof. F. G. Young, professor of biochemistry in the University of Cambridge, and Prof. A. Haddow, director of the Chester Beatty Research Institute, London, to the executive council of the Foundation to assist its scientific work.

Mr. Fred Smith, of Wm. Smith and Co., Ltd., Cliffe Dyeworks, Bruntcliffe, succeeds the late Mr. F. L. Goodall as president of the Society of Dyers and Colourists. Mr. Smith has been associated with the Society for more than forty years, being a vicepresident since 1939 , and for his exceptional services he was awarded in 1947 the Society's Gold Medal.

Dr. H. T. Openshaw, formerly Purdie lecturer in chemistry in the University of St. Andrews, has been appointed head of the Chemical Division of the Wellcome Research Laboratories, Beckenham, in succession to Dr. D. W. Adamson, who last year became research director of the Wellcome Foundation, Ltd., and director of the Wellcome Research Laboratories (see Nature, 172, 654; 1953).

THE following have been appointed to lectureships in the University of Sheffield : E. J. Sarginson (civil engineering) and J. R. Metcalf (mining).

OWING to illness, Sir Geoffrey Taylor was unable to deliver the thirty-eighth Guthrie Lecture before the Physical Society last March. He will now give it on September 24 in the Lecture Theatre of the Science Museum, Exhibition Road, London, S.W.7, at 5 p.m., his subject being "Diffusion and Mess Transport in Tubes". The Lecture will be open to the general public.

The Oliver Memorial Fund is offering an award of $£ 50$ to a British subject for original work or services in connexion with research, organization or the donor aspect of blood transfusion. Applications or information directing attention to suitable candidates must be submitted before August 31 to the honorary treasurer. of the Fund, F. W. Mills, c/o National Provincial Bank, Ltd., Holborn Circus, London, E.C.1.

THE Textile Institute, 10 Blackfriars Street, Manchester 3, will hold a conference on "Fibre Friction" in Ghent during September 9-13, this being the first conference that the Institute will have held outside Great Britain since 1928. It is noteworthy that the Institute's first overseas meeting was in Ghent during 1913. For the present conference, the Institute has received the co-operation of the Centre Scientifique et Technique de l'Industrie Textile Belge, the University of Ghent and the organizers of the Ghent International Trade Fair, which will be in progress at the time. Seven papers will be read by British, Belgian and Dutch scientific workers.

A symposium on "The Vegetation Types of India" will be held by the Indian Botanical Society in Baroda during December 31-January 1. Among the types of vegetation of the different regions of India to be discussed will be forests, grasslands, aquatic vegetation, mangrove, desert vegetation, and vegetation of other habitats such as sand dunes, silted banks, eroded and barren areas. The ecological accounts will be given under the following headings: climate, geology and soils, biotic features, floristic composition, succession and climaxes. Copies of papers for the symposium should be submitted before September 1 to Dr. R. Misra, Department of Botany, University of Saugar, Sagar, India, from whom all further information can be obtained. 